\title{
Neurofibromatosis Type 1 Lately Revealed by Solitary Nipple-Areola Neurofibromas
}

\author{
Mehdi Khallaayoune*, Sanae Sialiti, Fatima Ezzahra Elgaitibi, Mariame Meziane and Karima Senouci \\ Department of Dermatology, Ibn Sina University Hospital, Mohammed V University, Rabat-Morocco
}

Submission: August 27, 2020; Published: August 31, 2020

*Corresponding author: Mehdi Khallaayoune, Department of Dermatology, Ibn Sina University Hospital, Mohammed V University, Rabat-Morocco

\begin{abstract}
Abstarct
Neurofibromatosis type 1 is a dominant autosomal genetic disorder characterized by a multitude of skin lesions associated with various abnormalities of nervous system, eye and Bones. Nipple-areola is a rare localization of neurofibromatosis that may be misleading especially when other dermatological signs are discreet. We hereby report a case of a 34 years old woman which was referred for suspect nipple-areola tumours revealing a misdiagnosed neurofibromatosis type 1 . We believe that gynaecologists should be familiar with this presentation as it may be associated with other systemic complications or even breast carcinoma.
\end{abstract}

Keywords: Neurofibromatosis type 1; Nipple-areola; Neurofibroma

\section{Introduction}

Neurofibromatosis type1 is one of the most frequent genodermatosis. Neurofibromas are a very evocative skin manifestation encountered in $95 \%$ of patients. Nipple-areola involvement is rare and has been poorly described. It may appear atypical to many gynaecologists especially when NF1 diagnosis is not yet known. However diagnosis should be kept in mind as patients must be assessed for other systemic complications of neurofibromatosis. We hereby report a case of 34 years old woman with nipple-areola neurofibromas revealing an undiagnosed neurofibromatosis.

\section{Case Report}

A 34-year-old single woman, with familial history of breast cancer, was referred for a suspect tumor of the nippleareola progressing for 4 months with no other signs. Physical examination revealed two pedunculated soft brownish lesions protruding from the right areola (Figure 1). No breast mass and no lymphadenopathy were found. Mammography and breast ultrasound were completely unremarkable. The rest of skin examination noticed discreet axillary and brest freckling with multiple café-au-lait spots (Figure 2). An ophthalmologic assessment was made, revealing few Lish nodules on the iris. The patient reported having the skin lesions from childhood but never consulted. Her mother was followed for breast carcinoma but never displayed the same skin lesions. Diagnosis of neurofibromatosis type 1 was retained on the basis of clinical arguments including axillary freckling, more than 6 café-au-lait spots over $15 \mathrm{~mm}$ size, and Lish nodules. Nipple-areola tumors were consistent with the diagnosis of superficial breast neurofibromas. Physical examination of both parents and sister did not show any neurofibromatosis sign suggesting a sporadic form.

Explanations and genetic counseling regarding her disease were given to patient. However she remained worried about an eventual malignant nature of the lesions. A surgical excision of both neurofibromas was performed to reassure the patient. Histological examination revealed spindled cell proliferation in the dermis with few lymphocytes and masts cells in a mucoïde background stroma (Figure 3). PS100 staining was positive (Figure 4) confirming diagnosis of localized neurofibroma.

After surgery, a close senological follow up was scheduled owing to the familial history of breast cancer. Complete testing for neurofibromatosis associated morbidities, including brain and bones imagery, blood pressure measurement and renal assessment, did not find any abnormalities.

\section{Discussion}

Neurofibromatosis type 1 is a dominant genetic disorder related to an altered expression of NF1 gene located on chromosome 17. Loss of tumour suppressor function may explain occurrence of variable benign and malignant tumours [1]. Neurofibromas are a 


\section{Journal of Gynecology and Women's Health}

hallmark of neurofibromatosis type 1 arising in 95\% of patients. They usually manifest after adolescence as soft brownish or fleshcoloured nodules sometimes pedonculated, mainly located on the trunk, the head and the neck. Breast localization is quite rare and usually concern nipple-areola complex [2]. It affect predominantly women with an increasing frequency following the age [3]. Breast neurofibromas often present as appendices of the nipple and areola resembling accessory nipple [4] or molluscum pendulum. Sometimes it may present as a massive breast neurofibromatosis deforming nipples and protruding as a bunch of grapes [4].

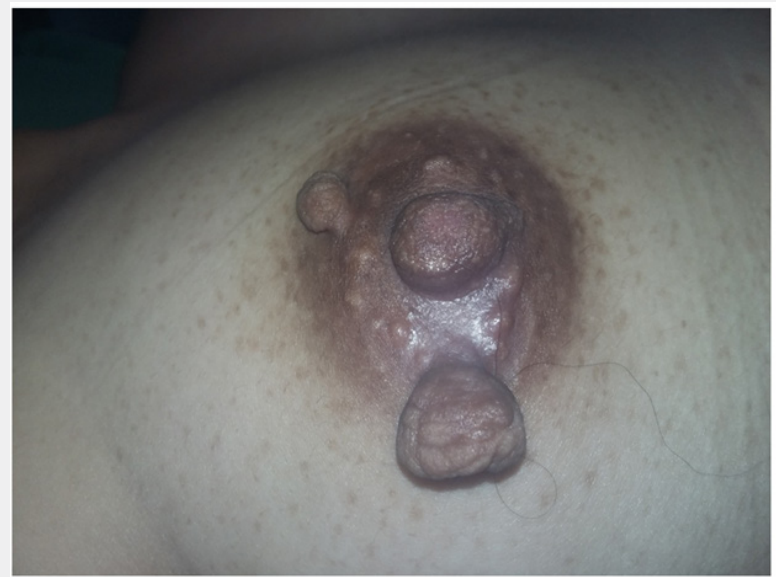

Figure 1: Soft brownish protruding nodules of the nipple-areola.

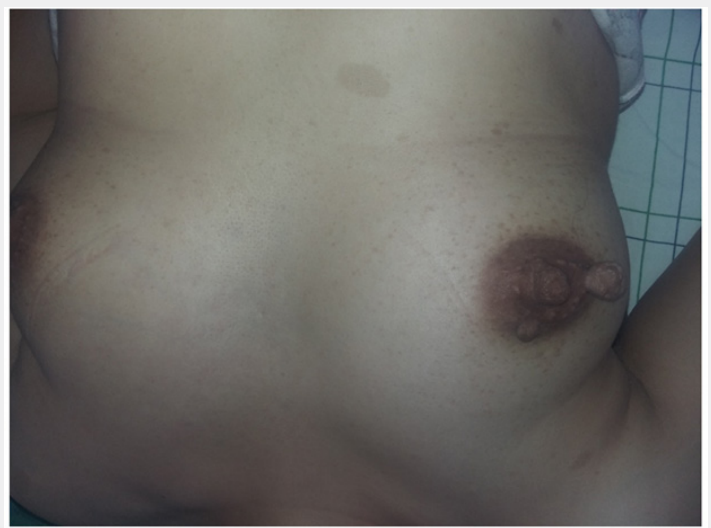

Figure 2: Discreet freckling around nipple-areola and café-au-lait spots on trunk.

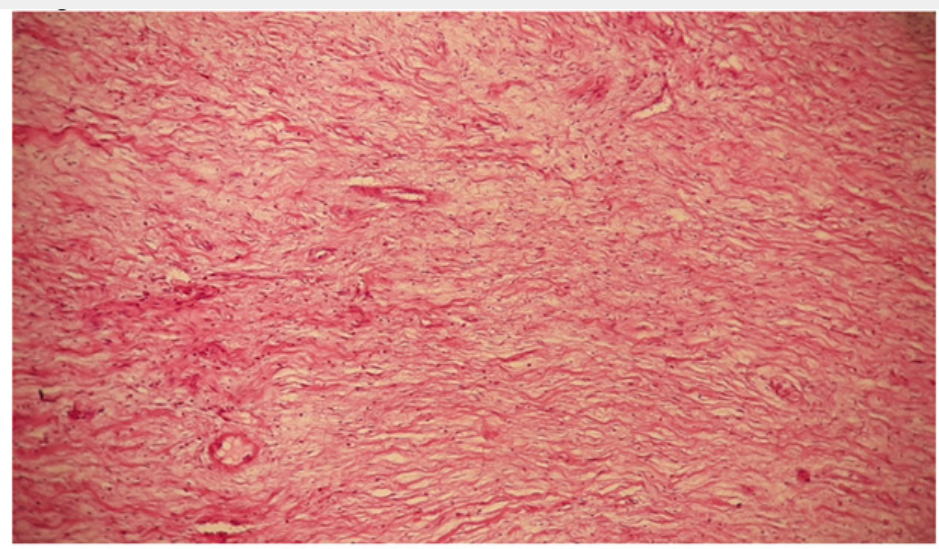

Figure 3: Spindle cell proliferation with few lymphocytes in a mucoïde background (HE magnification x20). 


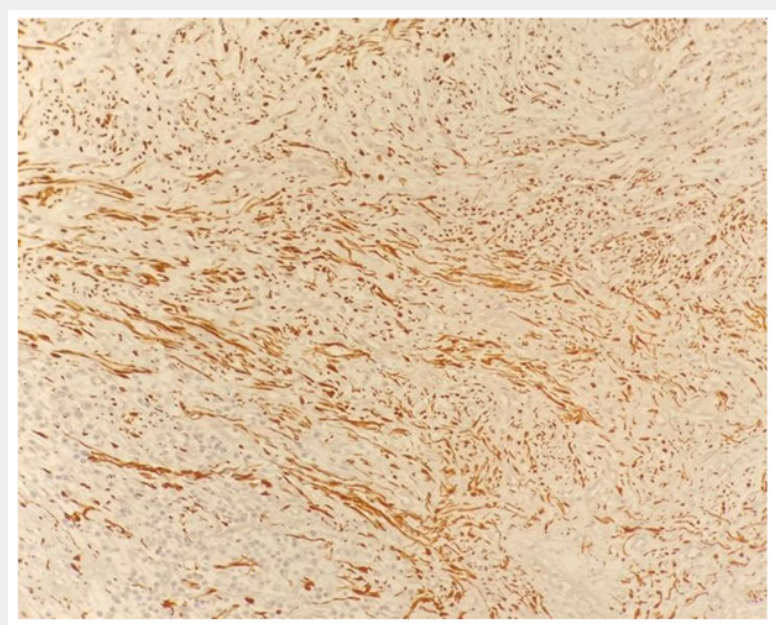

Figure 4: Diffuse positive PS100 staining (magnification x20).

NF1 phenotype is highly variable and there is no explanation for why some patients develop this special features and not others. Diagnosis can be made easily when NF1 presents with florid cutaneous stigmata. In the case of our patient, NF1 diagnosis was not known and there were surprisingly no other skin neurofibroma. Freckling and café-au-lait patches were discreet and did not draw attention of the patient. In such as case, complete skin examination appears very important to evoke the diagnosis. When surgical excision is performed histological diagnosis can be made. Typical features include dermal proliferation of randomly oriented thin spindled cells corresponding to Schwann cells, perineurial-like cells or fibroblastic cells, with few occasional lymphocytes or masts cells and a diffuse positive PS100 staining [5].

NF1 is associated is with higher risk in the development of several malignancies as optic gliomas, pheochromocytoma, astrocytomas and neurofibrosarcoma. There is also an increased risk of breast cancer developing with frequent delayed diagnosis owing to patients mistaking breast masses as neurofibromas and clinical detection difficulty [3]. Invasive ductal carcinomas, as much as invasive lobular carcinomas, metaplastic breast carcinoma and Paget's disease have all been reported. Localization of both BRCA1 gene and NF1 gene on chromosome 17q is a data consisting with this observation [6]. As a consequence early and rigorous clinic and imagery screening is highly recommended for this phenotype [2,3]. Surgical excision is the regular treatment for nipple-areola neurofibromas, and is mostly indicated for cosmesis. In some cases, plastic surgery may be needed for good aesthetic and functional results [7].

\section{Conclusion}

Neurofibromas of the nipple-areola complex are rare and may be misleading when diagnosis of neurofibromatosis is not known. Complete skin examination is necessary in such cases. There is a higher risk for developing breast carcinoma that should lead to a close clinic and mammographic follow-up.

\section{References}

1. Philpott C, Tovell H, Frayling IM, Cooper DN, Upadhyaya M, et al. (2017) The NF1 somatic mutational landscape in sporadic human cancers. Hum Genomics 11(1): 13.

2. Zhou Y, Pan B, Mao F, Zhu Q, Huo Z, et al. (2012) A Hidden Breast Lump Covered by Nipple Appendices in a Patient with von Recklinghausen Disease: A Case Report and Review of the Literature. Clin Breast Cancer 12(1): 71-75.

3. Bongiorno MR, Doukaki S, Aricò M (2010) Neurofibromatosis of the nippleareolar area: a case series. J Med Case Rep 4: 22.

4. Friedrich RE, Hagel C (2010) Appendices of the nipple and areola of the breast in neurofibromatosis type 1 patients are neurofibromas. Anticancer Res 30(5): 1815-1817.

5. Hero E, Carey M, Hero I, Shaaban AM (2018) Bilateral Neurofibromas of the Nipple-Areolar Complex: A Case Report and Approach to Diagnosis. Case Rep Pathol 30: 1815-1818.

6. Ceccaroni M, Genuardi M, Legge F, Lucci-Cordisco E, Carrara S, et al. (2002) BRCA1-related malignancies in a family presenting with von Recklinghausen's disease. Gynecol Oncol 86(3): 375-378.

7. Ferraro GA, Nicoletti G, Graziano P, Rossano F, D’Andrea F, et al. (2006) Late onset of von Recklinghausen's disease. Aesthetic Plast Surg 30(3): 370-372. 

(C) This work is licensed under Creative BY DOI: $10.19080 / J G W H .2020 .19 .556020$

\section{Your next submission with Juniper Publishers} will reach you the below assets

- Quality Editorial service

- Swift Peer Review

- Reprints availability

- E-prints Service

- Manuscript Podcast for convenient understanding

- Global attainment for your research

- Manuscript accessibility in different formats ( Pdf, E-pub, Full Tsext, Audio)

- Unceasing customer service

Track the below URL for one-step submission https://juniperpublishers.com/online-submission.php 